\title{
CONTRIBUTION TO THE DESIGN OF HYDRAULIC LIME-BASED GROUTS FOR MASONRY CONSOLIDATION
}

\author{
Luis G. BALTAZAR ${ }^{\mathrm{a}}$, Fernando M. A. HENRIQUES ${ }^{\mathrm{a}}$, Maria Teresa CIDADE ${ }^{\mathrm{b}}$ \\ ${ }^{a}$ Department of Civil Engineering, Universidade Nova de Lisboa, \\ Campus da Caparica, 2829-516 Caparica, Portugal \\ ${ }^{b}$ Department of Materials and CENIMAT/I3N, Universidade Nova de Lisboa, \\ Campus da Caparica, 2829-516 Caparica, Portugal
}

Received 07 Nov 2012; accepted 08 Jan 2013

\begin{abstract}
Grout is a concentrated suspension that can be employed for the homogenisation and consolidation of systems presenting pores, voids and cracks, such as inner core of old stone masonries. A grout should be well conceived, taking into account the optimisation of its performance; this means that simple binder and water formulations prove to be inadequate. Hence, the effect of different admixtures and pozzolans, which are traditionally used in concrete, on the fresh and hardened properties of hydraulic lime grouts, were investigated. Hydraulic lime binder plays a role of great importance in the rehabilitation of historic structures, due to its compatibility with pre-existing materials, like mortars. However, hardly any information is presently known regarding the effect of these materials on the behaviour of hydraulic lime grouts. The improvement of their properties through the use of these products is still an open field. Hence, and as a first step, the prediction of grout properties in a laboratory setting were made. The results summarised in this paper are part of a large research project and precede the fine tuning of grout composition according to the characteristics of the masonry to which such a grout is to be injected.
\end{abstract}

Keywords: hydraulic lime grout, silica fume, fly ash, superplasticiser, air entraining agent, masonry consolidation.

\section{Introduction}

Heritage or common old buildings represent the large majority of the construction types in many urban centres all over Europe. Their masonries are frequently in a bad state of conservation and present very different characteristics; some are made of a single leaf, others have multileaf walls. In the case of a multi-leaf wall, the section is composed by two resistant external leaves and an inner core filled by small stones, sand, mortar or other kind of unbounded material (Vintzileou 2011). The absence of cohesion among masonry elements, the existence of voids and cracks as well as the poor connection between leaves lead to masonry walls with non-monolithic behaviour. This means that the wall becomes brittle, namely under vertical and horizontal loads. In order to stabilise such walls and to prevent structural failure, grout injection is a widely used consolidation technique since the 80's (Vintzileou 2011; Miltiadou 1990).

Grout injection allows an increase in masonry compactness and creates bonds between the internal and external leaves, therefore improving the masonry's mechanical strength and monolithic behaviour. Grouts for injection should be adequately designed to achieve the best performance from an injectability and durability point of view. This means that one of the first steps in grout optimisation for masonry injection should focus on the effects of different pozzolans and admixtures that can be used to improve their properties and to make the grout consolidation more effective.

Grouts, by definition, are mixtures of a binder and water. However, those simple mixes are unable to perform efficient consolidation, therefore requiring the use of additional products. This study concerns the use of hydraulic lime grouts with different pozzolans, such as silica fume (SF) and fly ash (FA), and admixtures, such as superplasticiser (SP) and air entraining agent (AEA). These products significantly affect fresh grout properties (rheology, stability and water retention) which are directly related with those in the hardened state (mechanical strength, porosity). FA is a by-product of coal burning from thermal electric power stations, a very fine powder with pozzolanic properties that can react with calcium hydroxide $\left(\mathrm{Ca}(\mathrm{OH})_{2}\right)$ resulting from hydration of hydraulic lime. According to other researchers (Chindaprasirt et al. 2005a, b) it is expected that the partial replacement of hydraulic lime by FA contributes to improving

Corresponding author: Luis G. Baltazar

E-mail: luis.baltazar@fct.unl.pt 
grout fluidity, since the small and spherical FA particles improves contact between hydraulic lime particles by ball bearing action and reduce the friction forces. On the other hand, SF is an additive from electrometallurgy industry and can be applied as a fine filler whose particles fill the spaces made by the large and the long shape of hydraulic lime particles. Due to very fine SF particles among lime particles decrease of frictional forces between lime particles and a reduction of yield stress are expected (Lasker, Sudip 2008). Moreover, it is expected that high SF fineness increases the adsorption of water, thus allowing better water retention capabilities. However, these finer particles are the source of additional surface area resulting in an increase of contact forces among solid particles (Van-der-Waal's interactions) requiring the presence of a high range water reducer to minimize this problem, such as superplasticiser (Lasker, Sudip 2008; Artelt, Garcia 2008). According to Kadri (2009) the presence of SF also has a slight accelerating effect on the early age of strength development.

SP is a dispersant admixture whose action is based on repulsive forces; from a chemical point of view an SP is a surface active agent that acts on the binder particles by means of electrostatic charges and/or attaching long polymer chains over the particles, creating a repulsion between them (Martins, Bombard 2012). This repulsion action contributes to hold the particles far enough apart so that they cannot come together, and thus, particle flocculation is reduced or even prevented (Vickan 2005). Thus, through SP action an improvement of rheological parameters is expected, such as reduction of plastic viscosity and yield stress as well as a lower segregation. The addition of the SP causes a change in the rheological behaviour of cementitious grouts from shear thinning to quasi-Newtonian. However, it is well known that rheological behaviour of cementitious pastes with SP depends on type and dosage. AEA is a surfactant material which is a polymer molecule that has a hydrophilic polar head and a non-polar hydrophobic tail (Du, Folliard 2005). Taking into account that lime particles surfaces contain charges, the polar head group is adsorbed by the particles while the hydrophobic tail will become oriented into the air bubble present in the aqueous phase as a result of mix agitation. These small and well distributed air bubbles can act as inerts between the lime particles and the charges surrounding each air bubble causing their mutual repulsion which may improve mix fluidity (Seabra et al. 2009; Du, Folliard 2005; Ouyang et al. 2008). In addition, the adsorption of small air bubbles on the surface of the particles will prevent the sinking and consequently may improve grout stability through the reduction of segregation.

The choice of hydraulic lime (EN459-1 NHL5) as binder is a consequence of its chemical and physical properties being closer to those of the pre-existing materials in old masonries (Binda et al. 1997). So far admixtures and/or pozzolans have been widely used in the case of cement based mixtures, especially in the concrete industry, to improve the strength and durability of hardened structures (Rudzirnski 1984; Demir, Baspinar 2008; Chindaprasirt et al. 2005b). However, little information is presently known regarding the effect of these products on the behaviour of hydraulic lime mixtures compared to common cement based mixtures (Nguyen et al. 2011; Yahia, Khayat 2001; Huang 2001). There are a few studies of hydraulic lime grouts involving some of these products (Papayianni et al. 2010; Papayianni, Pachta 2012) however, the investigation of hydraulic lime pastes is still very incipient (Bras, Henriques 2009; Bras et al. 2010; Baltazar et al. 2012). For this reason, it is important to understand and determine the rheology, stability and mechanical properties of hydraulic lime grouts containing different types of admixtures and pozzolans.

\section{Scope and assumptions}

This study explores the influence of two different admixtures and pozzolans on the fresh and hardened properties of hydraulic lime grouts, based on the following experimental tests: (1) rheological measurements; rheology is a powerful tool to know if a grout has a proper flowability. Good flowability is an essential criterion to allow correct grout penetration inside the porous medium (inner core of masonry) and consequently the filling of the voids and cracks. Therefore, rheological properties such as yield stress and plastic viscosity, were determined; (2) stability; the stability analysis allows quantification of phase separation phenomena. Grout stability is an essential attribute to obtain better performance from a fresh state point of view. Phase separation phenomena, such as segregation and bleeding, cause lower homogeneity in the grout during and after injection. In an unstable grout the binder particles tend to settle after being injected into masonry, which causes a stratified flow and will therefore slow down the flow; (3) water retention test; this test allows to measure the amount of water that each sample can lose. Water retention capability is another important property since it represents the ability of a grout to retain the mixing water during its injection into dry and high absorptive porous medium. The preservation of mixing water is also of great importance since it causes not only a better fresh performance but also a proper hydration of hydraulic lime; (4) air content; this test method covers determination of the air content of fresh mixed grouts. It is well known that the air content at fresh state influences not only the grout flow ability but also its strength development, thus the air entrained was investigated; (5) mechanical strength; the grout mechanical strength, particularly the compressive strength, is of great importance, since the behaviour of grout hardened has a determinant effect on the mechanical properties of the grouted masonry; (6) the open porosity is another parameter analysed; in fact water 
is often present in historic buildings, which can come from different sources, and moisture transport inside the masonry is a potential cause of internal erosion of the wall. This way, it is of particular interest to have grouts with high porosity to facilitate the exit of water from masonry. Otherwise, only water vapour can be transported meaning a much slower process of losing water than when the water is able to proceed to the surface itself; (7) water vapour permeability was also analysed due to the fact that reduced water vapour permeability is a detrimental factor because it hampers the removal of water vapour which passes through masonry walls (Collepardi 1999).

The results summarised in this paper are part of a larger research study and precede the analysis of the performance of those grouts when injected into different porous media that simulate old masonry walls (Jorne et al. 2012). Only then, based on the injection tests, can the composition of these grouts be finely tuned by the variation of each component's concentration according to the characteristics of masonry to which such a grout is to be injected.

\section{Materials}

The hydraulic lime used is a EN459-1:2010 NHL5 (2010) produced in Portugal by Secil-Martingança, which has the characteristics presented in Table 1 according to the information provided by the manufacturer. The FA used is a class F according to ASTM C216 and was collected from a Portuguese thermal power plant; a commercially available SF was used, namely undensified silica fume produced by MAPEI. The chemical composition of the lime, fly ash and silica are given in Table 2. The SP based on polycarboxylate (Glenium Sky 617) produced by BASF was used, which has the characteristics presented in Table 3. The SP used belongs to the third generation whose repulsion is a combination of coupled steric and electrostatic effects, known as electrosteric repulsion. A commercially available AEA was used (Sika Aer-5) produced by SIKA, which has the characteristics presented in Table 3.

Table 1. Natural hydraulic lime characteristics

\begin{tabular}{|c|c|c|}
\hline $\begin{array}{l}\text { Compression strenght at } 7 \text { days } \\
(\mathrm{MPa})\end{array}$ & & .5 \\
\hline \multicolumn{3}{|l|}{ Fineness } \\
\hline & $90 \mu \mathrm{m}$ & $24.8 \%$ \\
\hline & $200 \mu \mathrm{m}$ & $2.9 \%$ \\
\hline \multicolumn{3}{|l|}{ Setting time } \\
\hline & Start & $2 \mathrm{~h} 45 \mathrm{~min}$ \\
\hline & End & $6 \mathrm{~h} 37 \mathrm{~min}$ \\
\hline Expansibility & $0.79 \mathrm{~mm}$ & \\
\hline
\end{tabular}

Table 2. Chemical characterization of hydraulic lime, fly ash and silica fume

\begin{tabular}{|c|c|c|c|}
\hline Formula & $\begin{array}{l}\text { Hydraulic } \\
\text { lime }(\%)\end{array}$ & Fly ash (\%) & $\begin{array}{l}\text { Silica fume } \\
(\%)\end{array}$ \\
\hline $\mathrm{Al}_{2} \mathrm{O}_{3}$ & 1.43 & 21.86 & 0.15 \\
\hline $\mathrm{CaO}$ & 5.54 & 8.23 & 0.2 \\
\hline $\mathrm{Fe}_{2} \mathrm{O}_{3}$ & 12.54 & 8.97 & 0.03 \\
\hline $\mathrm{Na}_{2} \mathrm{O}$ & 0.96 & 1.78 & 0.05 \\
\hline $\mathrm{MgO}$ & 0.78 & 1.74 & 0.3 \\
\hline $\mathrm{MnO}$ & 9.75 & 0.03 & - \\
\hline $\mathrm{SiO}_{2}$ & 62.88 & 48.75 & 97 \\
\hline $\mathrm{SiC}$ & - & - & 0.5 \\
\hline $\mathrm{SO}_{3}$ & 3.89 & 1.79 & - \\
\hline $\mathrm{P}_{2} \mathrm{O}_{5}$ & 1.01 & 0.89 & - \\
\hline $\mathrm{K}_{2} \mathrm{O}$ & 0.52 & 1.57 & 0.8 \\
\hline $\mathrm{TiO}_{2}$ & 3.30 & 1.37 & - \\
\hline $\mathrm{ZrO}_{2}$ & 1.29 & - & - \\
\hline Ignition loss & 19.84 & 1.74 & 2.05 \\
\hline Free lime & 3.89 & 4.34 & - \\
\hline $\begin{array}{l}\text { Blaine specific } \\
\text { surface }\left(\mathrm{cm}^{2} / \mathrm{g}\right)\end{array}$ & 5900 & 4010 & 12950 \\
\hline Density $\left(\mathrm{g} / \mathrm{cm}^{3}\right)$ & 2.70 & 2.50 & 2.25 \\
\hline
\end{tabular}

Table 3. Characteristic of admixtures

\begin{tabular}{lcc}
\hline Function & $\begin{array}{c}\text { Water surface } \\
\text { tension reducing }\end{array}$ & $\begin{array}{c}\text { High range water } \\
\text { reducing }\end{array}$ \\
\hline Commercial name & Sika Aer-5 & Glenium Sky 617 \\
\hline $\begin{array}{l}\text { Structure of the } \\
\text { material }\end{array}$ & $\begin{array}{c}\text { Naphthalene } \\
\text { sulphonate }\end{array}$ & Polycarboxylate \\
\hline Colour & Brown & Brown \\
\hline Density $\mathrm{g} / \mathrm{cm}^{3}$ & 1.04 & 1.05 \\
\hline $\mathrm{pH}$ & 11 & 8 \\
\hline Charge & Anionic & Anionic \\
\hline Chloride content $\%$ & 0 & $<0.10$ \\
\hline $\begin{array}{l}\text { Recommended } \\
\text { dosage range wt } \%\end{array}$ & $0.15-0.60$ & $0.30-0.90$ \\
\hline
\end{tabular}

\section{Experimental details}

\subsection{Grout compositions}

The grouts were prepared with a fixed water/binder ratio of 0.5. The pozzolans (FA and SF) were blended with the hydraulic lime at replacement ratio of $10 \%$ by lime weight. The grout mixtures were prepared with and without admixtures, a SP of polycarboxylate basis $(0.5 \%$ by weight of binder) was added and an AEA was used at a 
Table 4. Grout mix designs

\begin{tabular}{|c|c|c|c|c|c|c|c|}
\hline Notation & Constituents & $\begin{array}{c}\mathrm{SF} \\
(\mathrm{wt} \%)\end{array}$ & $\begin{array}{c}\mathrm{FA} \\
(\mathrm{wt} \%)\end{array}$ & $\begin{array}{c}\mathrm{SP} \\
(\mathrm{wt} \%)\end{array}$ & $\begin{array}{c}\text { AEA } \\
(w t \%)\end{array}$ & $\begin{array}{c}\text { water/ } \\
\text { binder (-) }\end{array}$ & $\begin{array}{c}\text { Lime } \\
(\mathrm{g})\end{array}$ \\
\hline Mix 1 & Lime & - & - & - & - & \multirow{9}{*}{0.5} & 1200 \\
\hline Mix 2 & Lime + SF & 10 & - & - & - & & 1080 \\
\hline Mix 3 & Lime + FA & - & 10 & - & - & & 1080 \\
\hline Mix 4 & Lime + SP & - & - & 0.5 & - & & 1200 \\
\hline Mix 5 & Lime + SP + SF & 10 & - & 0.5 & - & & 1080 \\
\hline Mix 6 & Lime + SP + FA & - & 10 & 0.5 & - & & 1080 \\
\hline Mix 7 & Lime + AEA & - & - & - & 0.5 & & 1200 \\
\hline Mix 8 & Lime + AEA + SF & 10 & - & - & 0.5 & & 1080 \\
\hline Mix 9 & Lime + AEA + FA & - & 10 & - & 0.5 & & 1080 \\
\hline SF & Silica fume & & & & & & \\
\hline FA & Fly ash & & & & & & \\
\hline SP & Superplasticiser & & & & & & \\
\hline AEA & Air entraining agent & & & & & & \\
\hline $\mathrm{W} / \mathrm{B}$ & Water to binder ratio & & & & & & \\
\hline
\end{tabular}

dosage of $0.5 \%$ by weight of binder. A total of nine different grout mixtures were performed as showed in Table 4.

\subsection{Mixing procedures}

The hydraulic lime grouts were prepared at room temperature $\left(20 \pm 2{ }^{\circ} \mathrm{C}\right)$ and a relative humidity of $60 \pm 2 \%$. For the preparation of grouts ordinary tap water, at a temperature of $18 \pm 2{ }^{\circ} \mathrm{C}$, was used and both pozzolans (SF or FA) and dry hydraulic lime were hand mixed to ensure a homogeneous distribution before the beginning of the mechanical mixing. The mixture procedure adopted was the following (Baltazar et al. 2012): the whole powder (lime + pozzolan) is added to $70 \%$ of total mix water and mixed for 10 minutes. The remaining water (with diluted SP or AEA) is added within $30 \mathrm{~s}$ (without stopping the mixer). After all materials had been added, the mixture was maintained for an additional 3 minutes at $800 \mathrm{rpm}$. At the end of mixing, each grout sample was passed through a sieve with $1.18 \mathrm{~mm}$ (no. 16 ASTM) before the experimental measurements. The delay of 10 minutes in the addition of SP makes hydraulic lime performance more effective because at early stages of hydration (first few minutes) a large amount of anhydrous phase is generated very rapidly $\left(\mathrm{C}_{3} \mathrm{~A}\right)$ and if SP is present, it becomes partly intercalated (co-precipitation) between layers of these hydrates, preventing them from exerting dispersing action (Flatt, Houst 2001).

\subsection{Rheological measurements}

Rheological properties were evaluated with a Bohlin Gemin HR $^{\text {nano }}$ rotational rheometer, equipped with a plate-plate geometry (with $\varnothing=40 \mathrm{~mm}$ ) and a gap of $2 \mathrm{~mm}$. The grout samples were analysed 10 minutes after the mixing process had ended. In all measurements the rheological protocol adopted was the following: a pre-shearing stage of $60 \mathrm{~s}$ at shear rate of $1 \mathrm{~s}^{-1}$ followed by $60 \mathrm{~s}$ at rest was applied. The pre-shearing of 60 deformation units was applied in order to ensure a similar initial state for all samples, since after mixing and depending on the time elapsed, the sample may be not exactly at the same stage and the pre-shear has the advantage of eliminate those small differences, before starting the rheological measurements. Then, the shear rate was increased from 0 to $300 \mathrm{~s}^{-1}$ (the maximum shear rate used). Each shear rate was applied long enough in order to ensure the attendance of the steady state, before measurements took place. The duration of each shear rate was determined through a single shear test and correspond to the time elapsed before viscosity became constant. $6 \mathrm{~s}$, for shear rates up to $4 \mathrm{~s}^{-1}$ and $2 \mathrm{~s}$ for shear rates higher than $4 \mathrm{~s}^{-1}$, were chosen. However, the total test time (without taking into account the pre-shear) was 2 minutes. All grout samples were analysed with a constant temperature of $20^{\circ} \mathrm{C}$, maintained by means of a temperature unit control. As mentioned above, the fresh grout properties can be used as control factors to analyse if a grout is suitable for injection, since a smaller yield value and plastic viscosity means an easier injection process and, consequently, lower pressures. Based on previous tests it is known that the rheological behaviour of fresh hydraulic lime grouts is shear-thinning, i.e. decrease in viscosity with increase in shear rate (Bras et al. 2010; Roussel et al. 2010). The results were interpreted using a rheology suspension framework, the Bingham model was used to fit the experimental data in order to determine plastic viscosity (Barnes 2000):

$$
\tau=\tau_{0}+\eta_{\mathrm{p}} \times \dot{\gamma}
$$

where: $\tau$ is the shear stress $(\mathrm{Pa}) ; \tau_{0}$ is the yield stress $(\mathrm{Pa})$; $\eta_{\mathrm{p}}$ is the plastic viscosity (Pa.s); $\dot{\gamma}\left(\mathrm{s}^{-1}\right)$ is the shear rate. 
In order to avoid an overestimation of the yield stress consequence of poor correlation between shear thinning part of flow curve and Eqn (1); the yield stress values were obtained from the correspondent shear stress values for a small shear rate, i.e. $\dot{\gamma}=0.5 \mathrm{~s}^{-1}$.

\subsection{Stability}

Grout stability was analysed measuring density variations, a procedure developed by Van Rickstal (Rickstal 2000). The grout samples were placed in a $500 \mathrm{ml}$ cup and a spherical object with a volume of $4.85 \mathrm{~cm}^{3}$ and a mass of $34.29 \mathrm{~g}$ was hanging above the grout and the immersed volume was calculated for each test. The sphere undergoes buoyancy according to Archimedes' Law. This force varies with grout density which changes when instability leads to the deposition of particles at the bottom of the cup causing a decrease in density in the top layers.

\subsection{Water retention capability}

The measurement of water retention was performed in accordance with the ASTM C941-02 (2002). This test determines the time required to remove a certain amount of water from the grout sample. A depression of $5.0 \pm 0.2 \mathrm{kPa}$ (controlled by digital manometer) was applied to a Bruckner funnel containing $500 \mathrm{ml}$ of the grout, while a graduated cylinder collected the removed water.

\subsection{Air content}

The evaluation of entrained air in the fresh grout was performed by means of pressure method, using a device in accordance with the EN 459-2 (2002). This device measures the air content of fresh grout based on the pressureto-volume relationship of Boyles-Mariotte Law. From observation of the change in volume of the grout sample with a change in pressure, the air content of each mix can be determined. The air content test is a simple test that was performed 2 minutes after mixer process had ended.

\subsection{Compressive strength}

Compressive strength was evaluated by means of five samples of each mix that were poured into oiled steel moulds $(160 \times 40 \times 40 \mathrm{~mm})$. After 5 days, the specimens were taken out of the moulds and cured in a controlled atmosphere, at $20 \pm 2{ }^{\circ} \mathrm{C}$ and $60 \%$ relative humidity, until the age of the compressive test. The compressive strength test was conducted at the maturity age of 7,14 and 28 days. A pre-load of $50 \mathrm{~N}$ was first applied before data collection commenced at a compression rate of $0.7 \mathrm{~mm} / \mathrm{min}$ to failure, using a Z050 Zwick mechanical test machine with $5 \mathrm{kN}$ capacity.

\subsection{Open porosity}

In order to analyse grout porosity the European Standard EN623-2 (1993) was adopted. The measurement method is based on the Archimedes' principle, and requires that the grout sample is fully saturated with water, from which the total open pore volume is calculated. In this method, the grout sample is fully saturated, depressurising and then pressurising the sample whilst it is fully immersed in water. The grout samples were cured in a controlled atmosphere, at $20 \pm 2{ }^{\circ} \mathrm{C}$ and $60 \%$ of relative humidity, until the maturity age of 28 days when the porosity test was carried out.

\subsection{Water vapour permeability}

The water vapour permeability test was performed applying the standard EN 1015-19 (1998), which is based on the variation of weights. The protocol was the following: an aluminum capsule was part filled with deionised water (about $1 \mathrm{~cm}$ of water) then a piece of cotton wool was placed over the water to avoid splashing during handing of the capsule. A moisture saturated ambient condition ( $\mathrm{RH} 98 \%$ ) was maintained in the cup, the perimeters of which were sealed with silicone paste. After the capsule was sealed the mass of the set (capsule + sample) was measured on a precision scale of $0.001 \mathrm{~g}$. The set was then placed into a climate chamber in which a stable moisture content and temperature of $40 \%$ and $23{ }^{\circ} \mathrm{C}$, respectively, were maintained. Under these conditions, the moisture gradient across the specimen promoted a water vapour flux. The mass of the set was recorded every 24 hours and the capsule was held in the climate chamber until a steady vapour flow was reached i.e. when the amount of water vapour through the sample per unit time reaches a constant value. Vapour diffusion coefficient was calculated at steady flow through the following expression:

$$
\pi=\frac{G . E}{\left(S . \Delta P .35 \times 10^{5}\right)},
$$

where: $G$ is the water vapour flow per unit of time at steady state $(\mathrm{Kg} / \mathrm{s}) ; S$ is the area of the sample $(75 \mathrm{~mm}$ diameter) $\left(\mathrm{m}^{2}\right) ; E$ is the sample thickness (m) and $\Delta P$ is the differential pressure of water vapour between the two sides of the sample $(\mathrm{Pa})$.

\subsection{SEM observations}

The microstructure of different grout samples, previously cured in a controlled atmosphere, at $20 \pm 2{ }^{\circ} \mathrm{C}$ and $60 \%$ of relative humidity, until the maturity age of 7 days, were carried out using a ZEISS DSM 962 Scanning Electron Microscope (SEM). The samples were previously coated using a POLARON SC502 and then examined by SEM at an accelerating voltage of $5 \mathrm{kV}$.

\section{Results and discussion}

\subsection{Rheological measurements}

Plots of variation of shear stress as a function of shear rate, for the different grout mixes, were analysed. Figure 1 shows the curves obtained from the mean values of at least three repetitions of each mix (i.e. the rheological tests have been performed on three different mixes having the same composition). The coefficient of variation $(\mathrm{CV})$, which is a mean variation coefficient for all the 
shear rates applied on each grout composition, is also given in Figure 1. The plastic viscosity values presented in Table 5 were calculated from the fitting of Eqn (1) to the experimental data. Figure 2 shows the rheological model adjusted to the linear part of the flow curve of mix 1 and 2. The yield stress values correspond to the shear stress measured at shear rate of $0.5 \mathrm{~s}^{-1}$. The authors are aware that, doing this, the values obtained may be overestimated, however they allow for comparison between different mixes.

From the results presented in Table 5 it is clear that SF has a harmful effect on grout rheological behaviour (mix 2). The addition of SF leads to an increase of specific surface, causing higher adsorption of water resulting in an increase of yield stress and plastic viscosity. According to the conclusions of Kadri and Aggoun (2009) the use of SF causes difficulties in workability of cementitious mixtures, since the cohesiveness of grout mixture improves when SF is present, which is due to an increase in the number of contact points between solid particles; thus, the presence of other admixtures such as SPs is required to solve this problem (Rao 2003). Indeed, when SP is added (mix 5) the fresh grout properties, such as yield stress and plastic viscosity, decrease compared to the grout without SP (mix 2). Note, however, that the results of mix 4 and 5 are not directly comparable, since

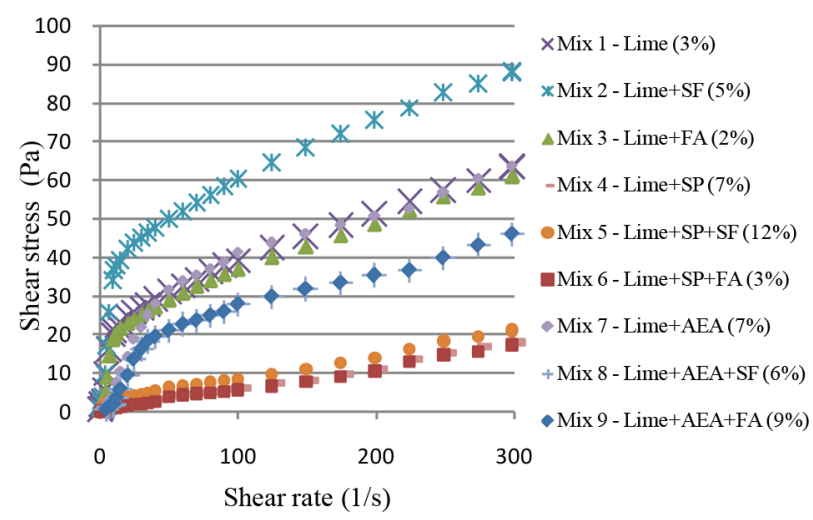

Fig. 1. Shear stress versus shear rate for different grout mixes Values in brackets give the $C V$

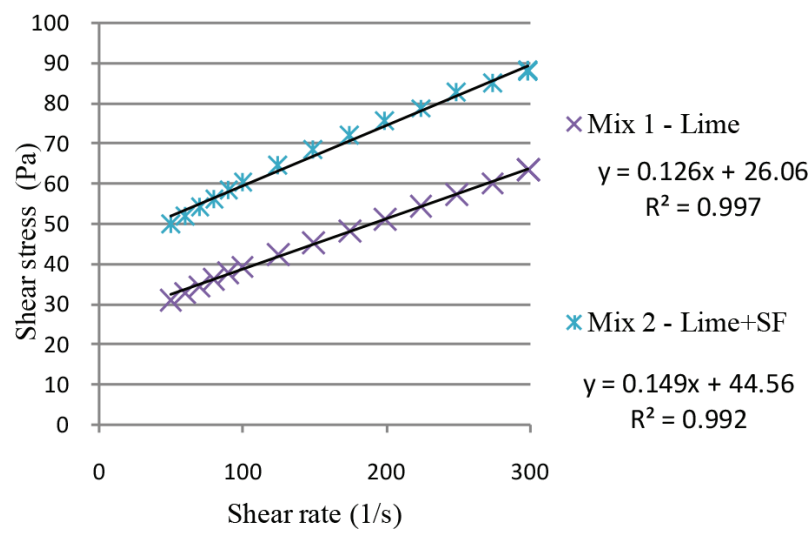

Fig. 2. Fitting the Bingham equation to the linear part of the flow curve of mix 1 and 2 the same dosage of SP has been used for all the mixes and, due to the high specific surface area of SF, the saturation dosage may be much larger for mix 5 than that for mix 4 .

Hydraulic lime replacement by FA results in a slight decrease in the rheological properties. This behaviour is probably due to the replacement of irregular hydraulic lime particles by FA particles with spherical morphology (Lasker, Sudip 2008), which contributes not only to a less mono-sized suspension but also to a lubricant effect between lime particles that facilitates the beginning of grout flow (reducing the yield stress), as can be seen by comparing the yield stress values of mix 1 and mix 3 . The FA does not adversely affect the rheological performance as SF does, because the FA particles are not as small as SF particles. Hence, for the same replacement percentage the FA has a lower surface area, thus resulting in a smaller adsorption of admixtures and consequently lower water consumption. This fact leads to an improvement in grout injectability through a slight reduction of yield stress and viscosity values.

From the values of rheological parameters (Table 5) it is clear that SP is the admixture that most contributes to a better grout rheological performance (as shown by mix 1 and 4, since SP imposes repulsive forces that prevent the solid particles from flocculation, resulting in a larger dispersion of the grout and a decrease in yield stress and lastic viscosity. In fact, the results show that SP incorporation is a necessity when SF is used. The grout with SP and FA (mix 6) shows the best rheological behaviour (the lowest yield stress and plastic viscosity), perhaps due to the combined effect of ball bearing action of FA particles and dispersing action of SP.

It is well known that rheological properties are affected by the air voids inside the grout microstructure. Hence, the small air bubbles, which work as a

Table 5. Rheological properties of grouts

\begin{tabular}{|c|c|c|c|c|}
\hline & & \multirow{2}{*}{$\begin{array}{l}\text { Yield } \\
\text { stress } \\
(\mathrm{Pa})\end{array}$} & \multicolumn{2}{|c|}{$\begin{array}{c}\text { Plastic viscosity } \\
\text { (Pa.s) }\end{array}$} \\
\hline & & & Value & $\mathrm{r}$ \\
\hline Mix 1 & Lime & 1.64 & 0.126 & 1.00 \\
\hline Mix 2 & Lime + SF & 2.36 & 0.150 & 0.99 \\
\hline Mix 3 & Lime + FA & 1.30 & 0.122 & 1.00 \\
\hline Mix 4 & Lime + SP & 0.50 & 0.061 & 0.99 \\
\hline Mix 5 & Lime $+\mathrm{SP}+\mathrm{SF}$ & 0.70 & 0.064 & 0.99 \\
\hline Mix 6 & Lime + SP + FA & 0.11 & 0.059 & 0.99 \\
\hline Mix 7 & Lime + AEA & 1.54 & 0.140 & 1.00 \\
\hline Mix 8 & Lime + AEA + SF & 2.15 & 0.172 & 1.00 \\
\hline Mix 9 & Lime + AEA + FA & 0.79 & 0.133 & 1.00 \\
\hline $\mathrm{SF}$ & \multicolumn{4}{|l|}{ Silica fume } \\
\hline FA & \multicolumn{4}{|l|}{ Fly ash } \\
\hline SP & \multicolumn{4}{|l|}{ Superplasticiser } \\
\hline AEA & \multicolumn{4}{|l|}{ Air entraining agent } \\
\hline & \multicolumn{4}{|c|}{$\begin{array}{l}\text { Correlation coefficient of Bingham model fitted to } \\
\text { the linear part of the rheograms }\end{array}$} \\
\hline
\end{tabular}


deformable inert in the mixture, help to disperse the hydraulic lime particles (Du, Folliard 2005). The AEA provides the production and fixation of small air bubbles on the particle surface that improves grout fluidity, owing to its ball bearing effect and without the drawback of water consumption as happens with SF or FA. That fact leads to a slight decrease in yield stress for grout with AEA (mix 7 and 9) when compared to the grouts without AEA. However, the behaviour of grouts with AEA and SF (mix 7) becomes worse. Once again this may be due to the effect of a very high specific surface area caused by SF fineness.

\subsection{Stability and water retention capability}

In Figures $3 a, 3 b$ and $3 c$ the effect of each product in grout stability and water retention for the nine mixtures tested is presented. The hydraulic lime replacement by SF (mix 2), which is an ultrafine powder whose particle dimension is at least 100 times smaller than hydraulic lime particle size, results in a suspension with dominant internal friction between closely-packed particles, that cause a reduction on grout stability (as shown in Fig. 3a), probably due to the aggregated particles that tend to sink by gravity. Even so, the presence of SF together with SP (mix 5) allows a significant improvement in grout stability as shown in Figure $3 b$. The presence of SF decreases the amount of free water available in the mixture (water that is not adsorbed by solid particles), mitigating the phase separation effect, and therefore contributing to a higher water retention capability. On the contrary, the addition of FA, since its lower specific surface will allows a higher amount of free water, leads to lower stability and water retention capability.

As expected, the use of the SP (mix 4) also improves stability and water retention regardless of the presence of SF or FA, as can be seen by comparing the results of the Figures $3 a$ and $3 b$. The influence of SP on stability and water retention is clear, resulting from several phenomena, such as: (1) the dispersing action of SP opposes sedimentation, so the sedimentation process occurs more slowly and the particles settle more homogeneously;

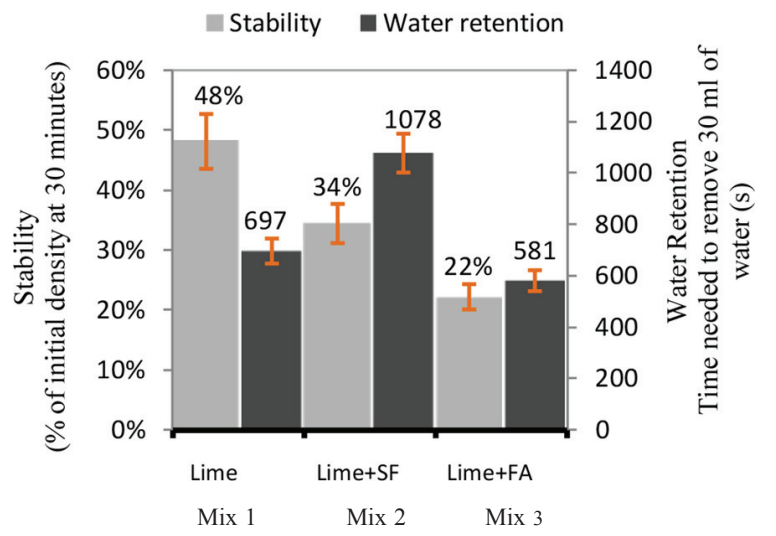

Fig. 3(a). Effect of pozzolans on stability and water retention of different grout mixes
(2) the SP de-flocculates grout particles, allowing a higher degree of wettability and consequently reducing the amount of free water (Mikanovic, Jolicoeur 2008).

From a stability and water retention point of view the use of AEA (mix 7) leads to the worse grout performance, when compared with the plain hydraulic lime grout (mix 1). This is in contrast to other researchers who claim that air bubble adsorption on the particle's surface could prevent the particles sinking (Du, Folliard 2005). Moreover, grout performance is further worsened with the presence of SF or FA (mix 8 and 9) which is due to an increase in surface area that enhances the amount of admixture adsorbed on particle's surfaces. Therefore, a lesser amount of AEA molecules are available for air bubble formation (Du, Folliard 2005). On the other hand, it can be seen in Figure 3c that an high water retention capability along with very low stability values was obtained in mixtures with SF and FA (mix 8 and 9). This may be due to the strong segregation phenomenon, since the particles sinking to the bottom prevent the extraction of water during the water retention test (as described in the procedure 3.5).

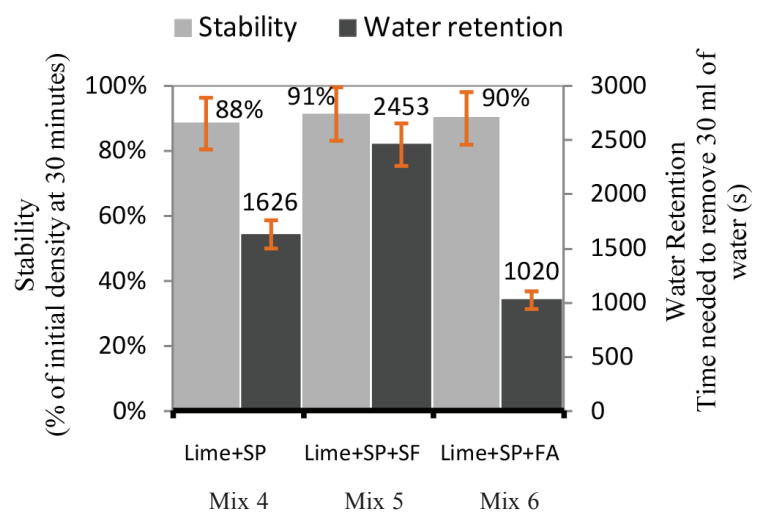

Fig. 3(b). Effect of pozzolans and SP on stability and water retention of different grout mixes

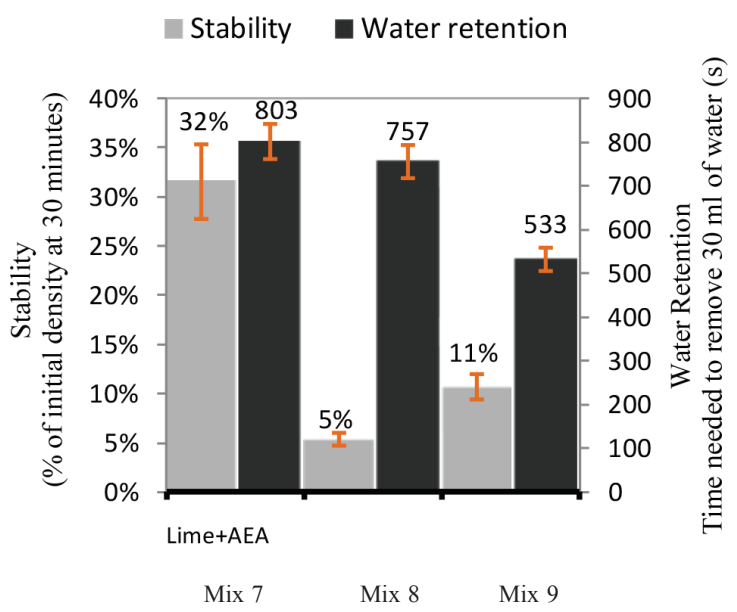

Fig. 3(c). Effect of pozzolans and AEA on stability and water retention of different grout mixes 


\subsection{Compressive strength and air content}

The variations on compressive strength of grouts at the maturity age of 7,14 and 28 days with different admixtures and pozzolans are shown in Figures $4 \mathrm{a}, 4 \mathrm{~b}$ and $4 \mathrm{c}$. The replacement of hydraulic lime by SF (mix 2) was found to be useful for the improvement of grout compressive strength; this results from the fact that SF leads to pozzolanic reactions, by means of reaction with $\mathrm{Ca}(\mathrm{OH})_{2}$, resulting in the formation of additional calcium silicate hydrate (C-S-H) structures (Shihada, Arafa 2010). It can be concluded from Figure $4 \mathrm{a}$ that SF accelerates the hydration process during the first seven days. This can be corroborated by the SEM photographs (Figs 5 and 6) where the difference is evident between the Ettringite formation between the mixtures without and with SF (mix 1 and 2, respectively). The data presented in Figure 8 a shows that the presence of SF leads to an increase of air incorporated in the fresh grout state. The authors attributed this behaviour to the partial replacement of hydraulic lime particles by smaller and with higher fineness SF particles, which produces an air-entraining effect. A similar effect was observed by Wang et al. (2010) with the incorporation of silica fume in cement mixture.

From the data presented in Figure $4 a$, it can be seen that FA does not significantly change compressive strength. Nevertheless, a slight decrease in grout strength can be observed when the FA is used as partial replacement of hydraulic lime. The authors are convinced that these lower compressive strengths in the FA grouts are due to the slow pozzolanic reaction of FA, since only a few parts of the FA participated in the hydration reaction during the early ages, acting only as filler (Jiang, Guan 1999). The slow hydration process caused by FA can be seen in Figure 4 by comparing the values of compressive strength between the mixtures with FA (mix 3, 6 and 9) and the plain hydraulic lime grout (mix 1). From the results of air content on fresh grout it can be seen that FA causes a similar effect as SF; although the increase in entrained air is less pronounced (Fig. 8a).

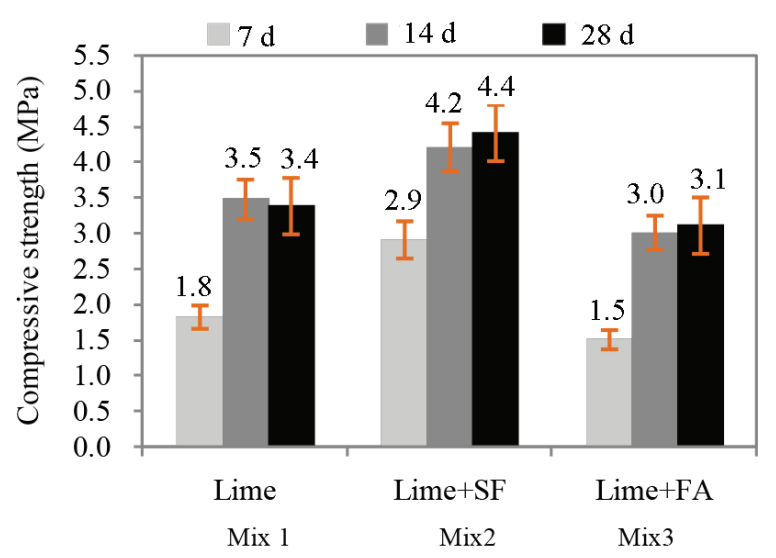

Fig. 4(a). Effect of pozzolans on the compressive strength of grouts
SP addition was found to be useful for the increment of grout compressive strength. In fact, the SP does not react by a chemical action on hydrated products; it affects the microstructure of the grout, and changes the morphology and size of lime hydration products (Demir, Baspinar 2008). The examination of the microstructure on grout fractured surface at the maturity age of 7 days shows that, instead of larger and well-defined crystals, smaller crystals are formed (Figs 5 and 7). Similar observations were noted by other authors (Yilmaz, Glasser 1989; Grabiec 1999). Cement mixtures with melamine based SP, present structures smoother and compacter when compared to cement mixtures without SP. The results obtained showed an increase in compressive strength with the presence of SP that may result from particles dispersion promoted by SP action, which simultaneously provides better lime hydration. Moreover, Fig. 8b shows that SP causes an increase in the air incorporated into the fresh grout state; however, the air entrained promoted by SP is smaller than the one caused by the AEA (Fig. 8c) as expected. Based on data presented in Figure 4 it can be noted that grout mixtures with AEA have a strength loss at the maturity age of 28 days. It is believed that strength loss may be due to expansive

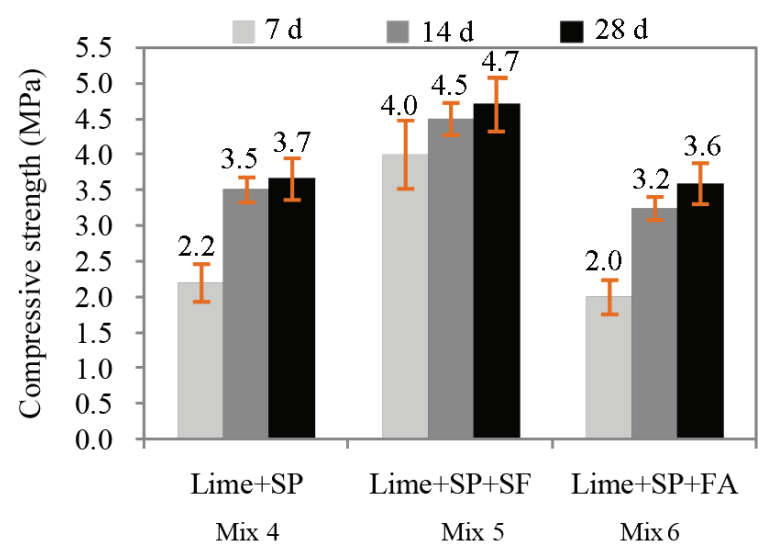

Fig. 4(b). Effect of pozzolans and SP on the compressive strength of grouts

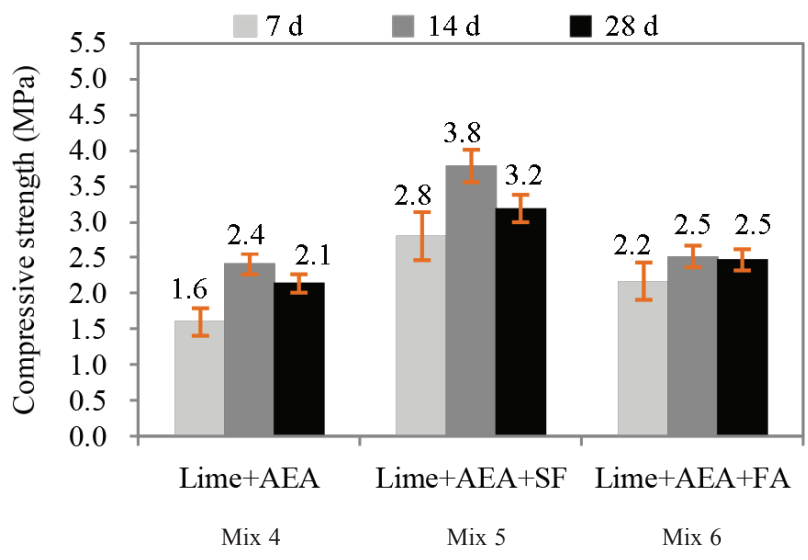

Fig. 4(c). Effect of pozzolans and AEA on the compressive strength of grouts 
Ettringite formation by reaction of sulphate with anhydrous or hydrated calcium aluminates (Collepardi 2003). However, this behaviour is noticeable in grout mixtures with AEA since the hardened grout structures are more brittle due to the introduction of air bubbles by means of AEA, which results in a significant decrease in compressive strength.

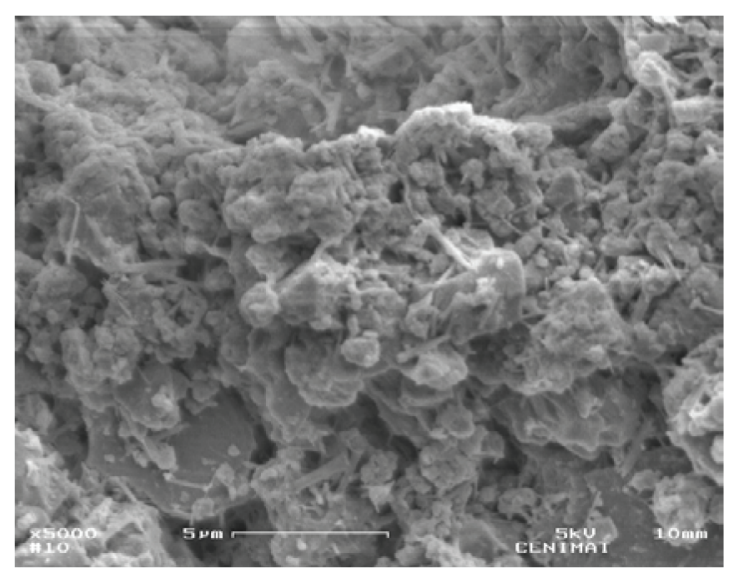

Fig. 5. SEM image of 7-days hardened grout without additives (mix 1$)$ at $5000 \mathrm{x}$

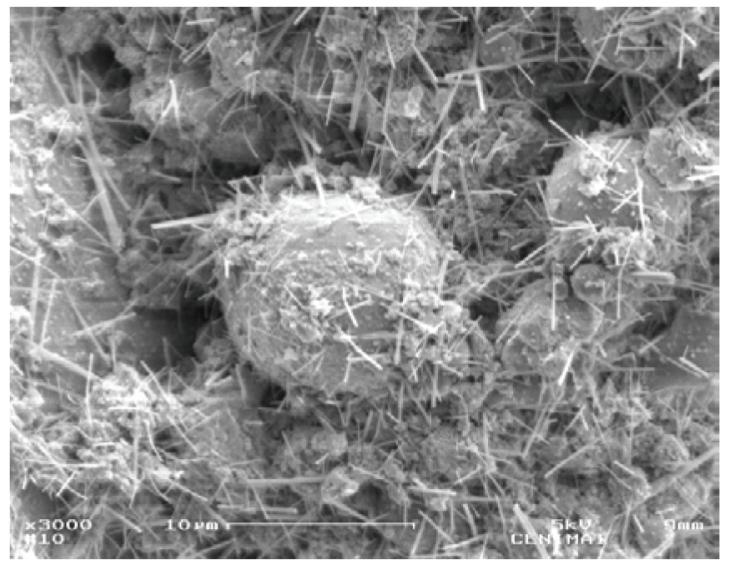

Fig. 6. SEM image of 7-days hardened grout with SF (mix 2) at $3000 x$

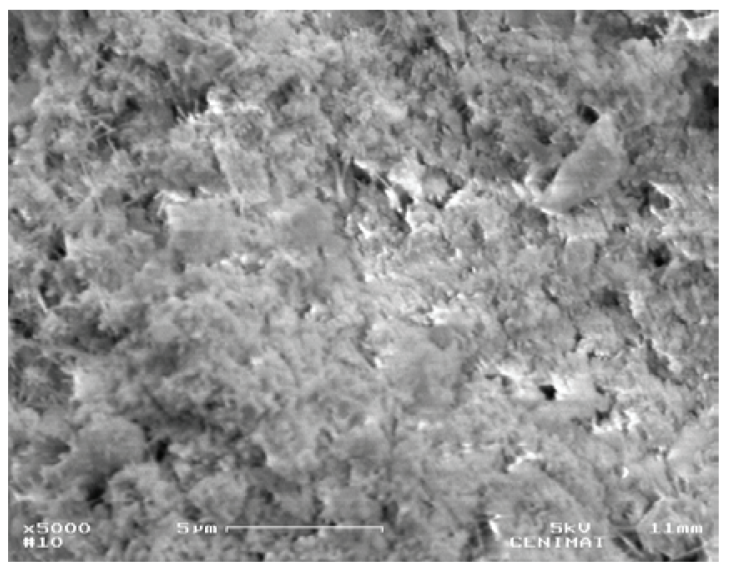

Fig. 7. SEM image of 7-days hardened grout with SP (mix 4) at $5000 \mathrm{x}$

\subsection{Water vapour permeability and porosity}

According to the results presented in Figure 9 there is hardly any variation in grout porosity when the different admixtures and/or pozzolans were used. However, changes can be observed in water vapour permeability for the different grout compositions. SF and FA

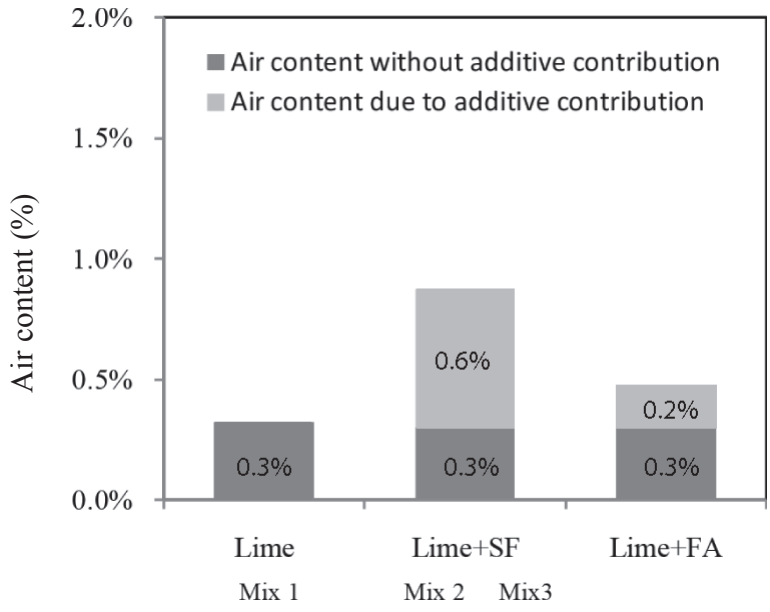

Fig. 8(a). Effect of pozzolans on air content of fresh grouts

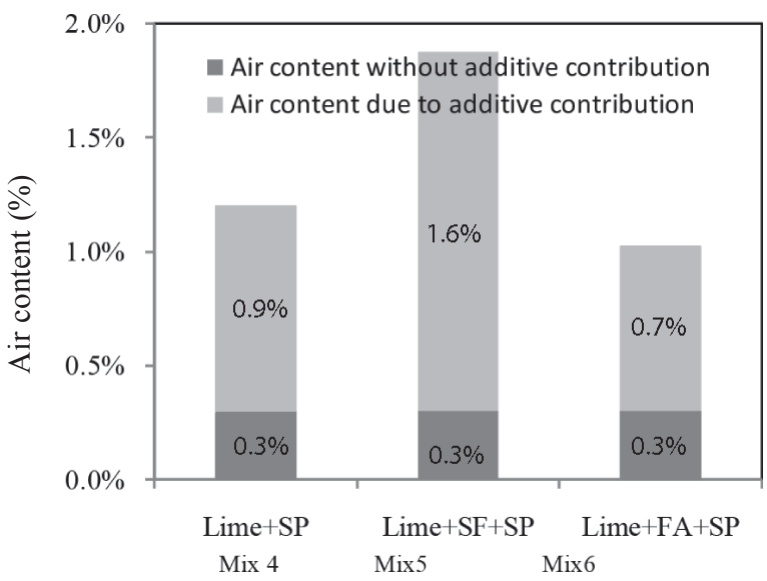

Fig. 8(b). Effect of pozzolans and SP on air content of fresh grouts

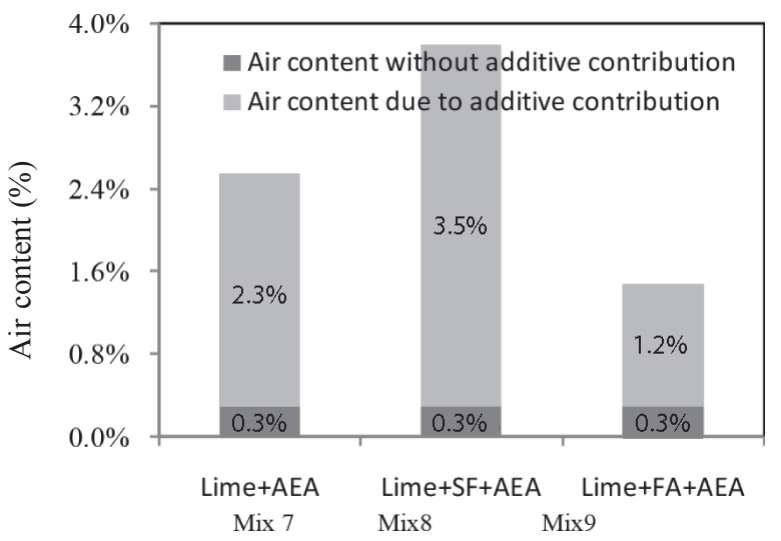

Fig. 8(c). Effect of pozzolans and AEA on air content of fresh grouts 
(Fig. 9a-mix 2 and 3) cause reduction of water vapour permeability as a consequence of their contribution to lime hydration and, consequently, to the formation of hydration products, which in turn leads to changes in the grout structure at the hardened state, as previously mentioned. On the other hand, AEA (mix 7) causes a slight increase in permeability, which is expected since this admixture contributes to the dispersion of the mixture, leading to higher pores, despite the fact that the overall porosity remains unchanged. This effect is due to the

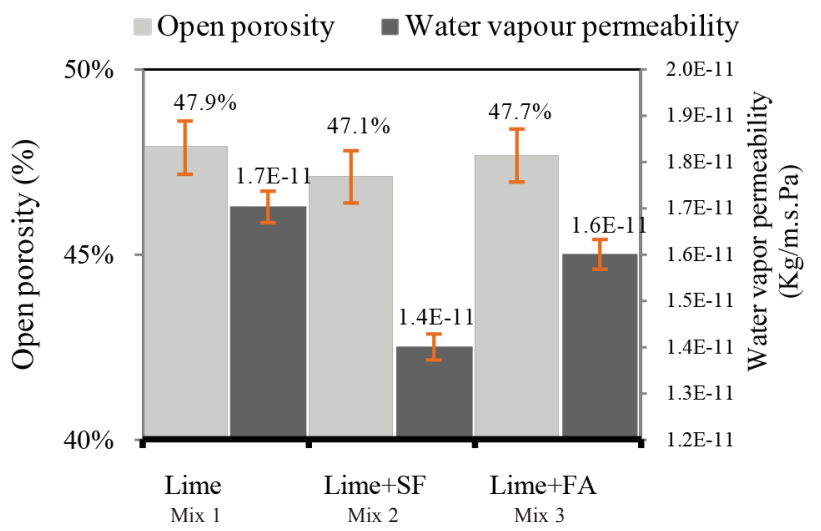

Fig. 9(a). Effect of pozzolans on water vapour permeability of grout

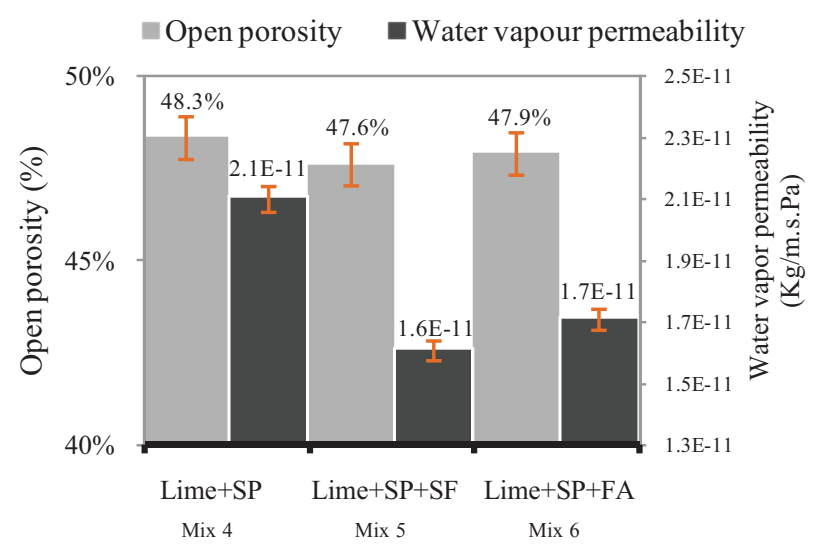

Fig. 9(b). Effect of pozzolans and SP on water vapour permeability of grout

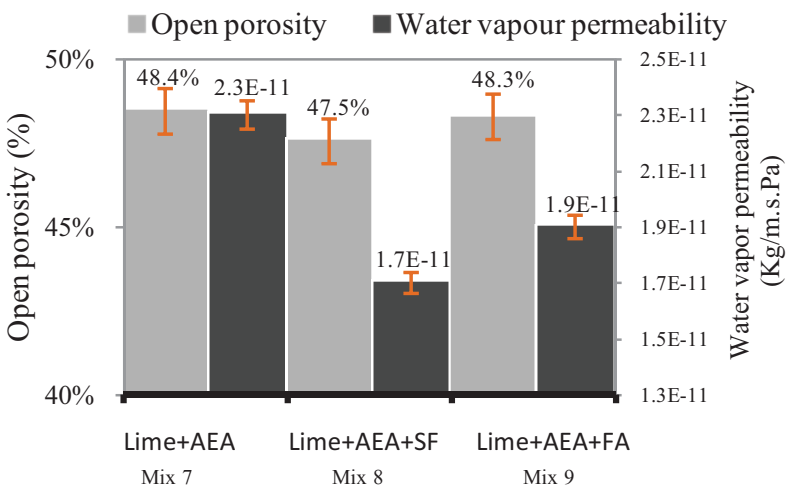

Fig. 9(c). Effect of pozzolans and AEA on water vapour permeability of grout tortuosity of the pore system. The tortuosity has nothing to do with the open porosity but entirely depends on the shape of pores and in an indirect way on the connections of the pore system (Hall, Hoff 2002). This means that for the same open porosity, we can have a very complex network of pores with very narrow throats and greater length of the path described by the pore space, which hinder the water vapour transport. In the opposite situation, such as with a very regular pore structure (low tortuosity) it facilitates passage of water vapour through the pore system, which provides grout with higher water vapour permeability. So, it can be noted that open porosity has little influence on water vapour permeability, since the same porosity provides different values of water vapour permeability.

\section{Conclusions}

From the results presented, the following conclusions can be drawn on the influence of different admixtures and pozzolans on some relevant properties of hydraulic lime grouts, from the masonry consolidation point of view:

1. Silica fume has a harmful effect on grout rheological behaviour, causing an increase of yield value and plastic viscosity. However, the replacement of hydraulic lime by silica fume (mix 2 ) was found to be useful for the improvement of grout compressive strength.

2. The hydraulic lime replacement by fly ash results in a slight decrease in yield stress. Nevertheless, the presence of fly ash leads to a decrease in grout compressive strength.

3. None of the admixtures or pozzolans analysed produced a variation in grout open porosity. However, a slight increase in water vapour permeability in the presence of superplasticiser and air entraining agent was observed.

4. The results indicate that superplasticiser is the admixture that most contributes to a better grout performance, from the rheological, stability and water retention point of view.

5. Superplasticiser addition was found to be useful for the increment of grout compressive strength.

6 . The presence of silica fume together with superplasticiser allows a significant improvement in the grout stability, as shown by mix 5 .

7. The grouts with fly ash and superplasticiser show the best rheological behaviour i.e. the lowest yield stress and plastic viscosity.

8. Air entraining agent is by far the worst admixture, since it leads to the worst grout performance, even when compared with the plain hydraulic lime grout. It is clear that, from a comprehensive point of view considering fresh and hardened-state results, products like superplasticiser are inevitable when designing a grout for injection purposes and its presence seems to be particularly required when other powder admixtures are used, such as silica fume. The authors recognise that these 
results should not be generalized, since the influence of the analysed admixtures will depend on other parameters that have not been considered in this study, such as the temperature conditions during mixing and grouting. In any case, this investigation demonstrated the potential of some products in the improvement of fresh and hardened properties of hydraulic lime grouts and precedes the grout composition optimisation and also the analysis of the performance of those grouts when injected into different porous media that simulate old masonry walls (Jorne et al. 2012). It is believed that only in this way can longterm performance of grouts be envisaged and properly evaluated.

\section{References}

Artelt, C.; Garcia, E. 2008. Impact of superplasticizer concentration and of ultra-fine particles on the rheological behaviour of dense mortar suspensions, Cement and Concrete Research 38(5): 633-642.

http://dx.doi.org/10.1016/j.cemconres.2008.01.010

ASTM designation C938-02. 2002. Standard practice for proportioning grout mixtures for preplaced-aggregate concrete. $6 \mathrm{p}$.

Baltazar, L. G.; Henriques, F. M. A.; Jorne, F. 2012. Optimisation of flow behaviour and stability of superplasticized fresh hydraulic lime grouts through design of experiments, Construction and Building Materials 35: 838-845. http://dx.doi.org/10.1016/j.conbuildmat.2012.04.084

Barnes, H. A. 2000. A handbook of elementary rheology. Institute of Non-Newtonian Fluid Mechanics, University of Wales. 200 p.

Binda, L.; Modena, C.; Baronio, G.; Abbaneo, S. 1997. Repair and investigation techniques for stone masonry walls, Construction and Building Materials 11(3): 133-142. http://dx.doi.org/10.1016/S0950-0618(97)00031-7

Bras, A.; Henriques, F. M. A. 2009. The influence of the mixing procedures on the optimization of fresh grout properties, Materials and Structures 42(10): 1423-1432. http://dx.doi.org/10.1617/s11527-008-9461-z

Bras, A.; Henriques, F. M. A.; Cidade, M. T. 2010. Effect of environmental temperature and fly ash addition in hydraulic lime grout behaviour, Construction and Building Materials 24(8): 1511-1517. http://dx.doi.org/10.1016/j.conbuildmat.2010.02.001

Chindaprasirt, P.; Buapa, N.; Cao, H. T. 2005a. Mixed cement containing fly ash for masonry and plastering work, Construction and Building Materials 19(8): 612-618. http://dx.doi.org/10.1016/j.conbuildmat.2005.01.009

Chindaprasirt, P.; Jaturapitakkul, C.; Sinsiri, T. 2005b. Effect of fly ash fineness on compressive strength and pore size of blended cement paste, Cement \& Concrete Composites 27(4): 425-428. http://dx.doi.org/10.1016/j.cemconcomp.2004.07.003

Collepardi, M. 1999. Thaumasite formation and deterioration in historic buildings, Cement \& Concrete Composites 21(2): $147-154$ http://dx.doi.org/10.1016/S0958-9465(98)00044-4

Collepardi, M. 2003. A state-of-the-art review on delayed ettringite attack on concrete, Cement \& Concrete Composites 25(4-5): 401-407.

http://dx.doi.org/10.1016/S0958-9465(02)00080-X

Demir, I.; Baspinar, M. S. 2008. Effect of silica fume and expanded perlite addition on the technical properties of the fly ash-lime-gypsum mixture, Construction and Building Materials 22(6): 1299-1304.

http://dx.doi.org/10.1016/j.conbuildmat.2007.01.011
Du, L.; Folliard, K. J. 2005. Mechanisms of air entrainment in concrete, Cement and Concrete Research 35(8): 1463-1471.

http://dx.doi.org/10.1016/j.cemconres.2004.07.026

EN 459-2. 2002. Building lime - Part 2: Test methods. 42 p.

EN 623-2. 1993. Advanced Technical Ceramics - Part 2: Determination of density and porosity. $16 \mathrm{p}$.

EN 1015-19. 1998. Methods of test for mortar for masonry Part 19: Determination of water vapour permeability of hardened rendering and plastering mortars. $12 \mathrm{p}$.

Flatt, R. J.; Houst, Y. F. 2001. A simplified view on chemical effects perturbing the action of superplasticizers, Cement and Concrete Research 31(8): 1169-1176. http://dx.doi.org/10.1016/S0008-8846(01)00534-8

Grabiec, A. M. 1999. Contribution to the knowledge of melamine superplasticizer effect on some characteristics of concrete after long periods of hardening, Cement and Concrete Research 29(5): 699-704.

http://dx.doi.org/10.1016/S0008-8846(99)00024-1

Hall, C.; Hoff, W. D. 2002. Water transport in brick, stone and concrete. London: Taylor and Francis. 318 p. http://dx.doi.org/10.4324/9780203301708

Huang, W.-H. 2001. Improving the properties of cement-fly ash grout using fiber and superplasticizer, Cement and Concrete Research 31(7): 1033-1041. http://dx.doi.org/10.1016/S0008-8846(01)00527-0

Jiang, W.; Guan, Y. 1999. Pore structure and its effect on strength of high-volume fly ash pastes, Cement and Concrete Research 29(4): 631-633.

http://dx.doi.org/10.1016/S0008-8846(99)00034-4

Jorne, F.; Henriques, F. M. A.; Baltazar, L. G. 2012. Grout injection in porous media with different internal structures, in Proc. $14^{\text {th }}$ International Conference - Structural Faults \& Repair, 3-5 July 2012, Edinburgh, Scotland.

Kadri, E.-H.; Aggoun, S. 2009. Interaction between $\mathrm{C}_{3}$ A, silica fume and naphthalene sulphonate superplasticiser in high performance concrete, Construction and Building Materials 23(10): 3124-3128. http://dx.doi.org/10.1016/j.conbuildmat.2009.06.026

Lasker, A. I.; Sudip, T. 2008. Rheological behavior of high performance concrete with mineral admixtures and their blending, Construction and Building Materials 22(12): 2345-2354.

http://dx.doi.org/10.1016/j.conbuildmat.2007.10.004

Martins, R. M.; Bombard, A. J. F. 2012. Rheology of fresh cement paste with superplasticizer and nanosilica admixtures studied by response surface methodology, Materials and Structures 45(6): 905-921. http://dx.doi.org/10.1617/s11527-011-9807-9

Mikanovic, N.; Jolicoeur, C. 2008. Influence of superplasticizers on the rheology and stability of limestone and cement pastes, Cement and Concrete Research 38(7): 907-919. http://dx.doi.org/10.1016/j.cemconres.2008.01.015

Miltiadou, A. 1990. Contribution à l'étude des coulis hydraulique pour la réparation et le renforcement des structures et des monuments historiques en maçonnerie. $\mathrm{PhD}$ thesis. ENPC, Paris.

Nguyen, V.-H.; Remond, S.; Gallias, J.-L. 2011. Influence of cement grouts composition on the rheological behaviour, Cement and Concrete Research 41(3): 292-300. http://dx.doi.org/10.1016/j.cemconres.2010.11.015

Ouyang, X.; Guo, Y.; Qiu, X. 2008. The feasibility of synthetic surfactant as an air entraining agent for the cement matrix, Construction and Building Materials 22(8): 1774-1779. http://dx.doi.org/10.1016/j.conbuildmat.2007.05.002

Papayianni, I.; Pachta, V. 2012. High performance lime based grouts for repair of historic masonries, in Proc. $8^{\text {th }}$ International Conference on Structural Analysis of Historical Constructions, 15-17 October 2012, Wroclaw, Poland. 
Papayianni, I.; Stefanidou, M.; Pachta, V. 2010. Grouts for injection of historical masonries: influence of the binding system and other additions on the properties of the matrix, in Proc. $2^{\text {nd }}$ Historic Mortars Conference \& Rilem TC 203-RHM 'Repair Mortars for Historic Masonry' Final Workshop, 22-24 September 2010, Prague, Rilem, 1123-1134.

Rao, G. A. 2003. Investigations on the performance of silica fume-incorporated cement pastes and mortars, Cement and Concrete Research 33(11): 1765-1770. http://dx.doi.org/10.1016/S0008-8846(03)00171-6

Rickstal, F. V. 2000. Grout injection of masonry, scientific approach and modeling. $\mathrm{PhD}$ thesis. KU-Leuven.

Roussel, N.; Lemaître, A.; Flatt, R. J.; Coussot, P. 2010. Steady state flow of cement suspensions: a micromechanical state of the art, Cement and Concrete Research 40(1): 77-84. http://dx.doi.org/10.1016/j.cemconres.2009.08.026

Rudzirnski, L. 1984. The effect of fly ashes on the rheological behaviour of cement pastes, Materials and Structures 17(5): 369-373. http://dx.doi.org/10.1007/BF02478709

Seabra, M. P.; Paiva, H.; Labrincha, J. A.; Ferreira, V. M. 2009. Admixtures effect on fresh state properties of aerial lime based mortars, Construction and Building Materials 23(2): 1147-1153.

http://dx.doi.org/10.1016/j.conbuildmat.2008.06.008
Shihada, S.; Arafa, M. 2010. Effects of silica fume, ultrafine and mixing sequences on properties of ultra high performance concrete, Asian Journal of Materials Science 2(3): 137-146. http://dx.doi.org/10.3923/ajmskr.2010.137.146

Vickan, H. 2005. Rheology and reactivity of cementitious binders with plasticizers. $\mathrm{PhD}$ thesis. Norwegian University of Science and Technology.

Vintzileou, E. 2011. Three-leaf masonry in compression, before and after grouting: a review of literature, International Journal of Architectural Heritage 5(4-5): 513-538. http://dx.doi.org/10.1080/15583058.2011.557137

Wang, X. H.; Jacobsen, S.; Lee, S. F.; He, J. Y.; Zhang, Z. L. 2010. Effect of silica fume, steel fiber and ITZ on the strength and fracture behavior of mortar, Materials and Structures 43(1-2): 125-139. http://dx.doi.org/10.1617/s11527-009-9475-1

Yahia, A.; Khayat, K. H. 2001. Experiment design to evaluate interaction of high-range water reducer and antiwashout admixture in high-performance cement grout, Cement and Concrete Research 31(5): 749-757. http://dx.doi.org/10.1016/S0008-8846(01)00496-3

Yilmaz, V. T.; Glasser, F. P. 1989. Influence of sulphonated melamine formaldehyde superplasticizer on cement hydration and microstructure, Advances in Cement Research 2(7): 111-119. http://dx.doi.org/10.1680/adcr.1989.2.7.111

Luis G. BALTAZAR. Master in Civil Engineering, PhD student at the Civil Engineering Department of New University of Lisbon (UNL), Research Fellow on the research project 'Advanced Grouts for Masonry Consolidation'. Main topics of interest: rheology of suspensions, optimisation of grouts for structural consolidation of masonry walls, design of experiments (DOE).

Fernando M. A. HENRIQUES. PhD in Civil Engineering, full Professor at the Civil Engineering Department of New University of Lisbon (UNL), Coordinator of the research project 'Advanced Grouts for Masonry Consolidation', Coordinator of the Construction and Hydraulics Division. Main topics of interest: architectural conservation (member of the permanent scientific committee of World Monuments Fund - Portugal), grouts and their application in old masonries, hygrothermal performance of buildings.

Maria Teresa CIDADE. PhD in Materials Science, Professor at the Materials Science Department of Faculty of Sciences and Technology of New University of Lisbon (UNL). Her main research interest is in rheology of complex fluids, in particular, polymers and liquid crystals. 